V. Zozulia, Master, valeriiaz@bigmir.net,

J. Shatrava, Lead Engeneer.

T. Sliva, PhD,

V. Ovchynnikov, PhD,

V. Amirkhanov, Dr. Sci.

Taras Shevchenko National University of Kyiv, Kyiv

\title{
COORDINATION COMPOUNDS OF COBALT AND COPPER BASED ON CAPH LIGAND N,N'-DIBENZYL-N"-TRICHLORACETYLPHOSPHORIC TRIAMIDE
}

Carbacylamidophosphates is a class of organic compounds having a composition -C(O)NHP(O)=. The presence of both peptide and phosphoramidic groups in the same molecule causes a wide range of inherent biological properties. On the basis of the ligand of the carbacylamide phosphorus type (CAPh ligand) N, N'-dibenzyl-N"-trichloroacetylphosphoric triamide (HL), di- and tetramer coordination compounds were synthesized: cobalt (II) $\mathrm{Co}_{2} \mathrm{~L}_{4}\left(\mathrm{CH}_{3} \mathrm{OH}\right)_{2}$ and copper (II) $\mathrm{Cu}_{4} \mathrm{~L}_{4}\left(\mathrm{OCH}_{3}\right)_{4}$. The composition and structure of the synthesized compounds was studied using the methods of IR spectroscopy, thermogravimetric and X-ray diffraction analysis. The bidentate-cyclic coordination of ligands through oxygen atoms of the phosphoryl and carbonyl groups was established on the basis of X-ray structural analysis data. In the $\mathrm{Co}_{2} \mathrm{~L}_{4}\left(\mathrm{CH}_{3} \mathrm{OH}\right)_{2} \mathrm{Complex} \mathrm{Conic}_{\mathrm{CObalt}}$ associates together forming centroscopic dimers due to the bridging function of the phosphoryl group. The coordination sphere also includes methanol molecules, which are coordinated to the metal atom and additionally linked to the oxygen atom of the carbonyl group by hydrogen bonding, which can be considered as an additional stabilizing factor in the formation of the dimeric structure. The copper compound is a $\mathrm{Cu}_{4} \mathrm{~L}_{4}\left(\mathrm{OCH}_{3}\right)_{4}$ tetramer, in which methylate ion through $\mathrm{M}_{3}$-bridging coordination bind four copper atoms to a tetramer. According to the thermogravimetric data, the first mass loss for the cobalt complex is observed in the range from $80^{\circ} \mathrm{C}$ to $150^{\circ} \mathrm{C}$ and corresponds to the loss of two methanol molecules. On the TGA curve, two exothermic effects are observed at temperatures of $218^{\circ} \mathrm{C}$ and $269^{\circ} \mathrm{C}$, which are due to the process of oxidative degradation of organic ligands. Unlike the compound of cobalt, the tetramer complex of copper contains methylate ion, therefore the complex is resistant to a temperature of $110^{\circ} \mathrm{C}$; with further rise in temperature there is a destruction of the organic part of this complex. The DTA curve shows an exothermic effect at a temperature of $168^{\circ} \mathrm{C}$. Residues after the destruction of the complexes correspond to polyphosphates of copper and cobalt.

Keywords: carbacylamidophosphates, 3d-metals, coordination compounds.

УДК 546.732+546.562+546.47

DOI: https://doi.org/10.17721/1728-2209.2018.1(55).7

А. Аблятіпова, студ.,

Т. Беруашвілі, студ.,

К. Губіна, канд. хім. наук, gubina@agrotest.com Київський національний університет імені Тараса Шевченка, Київ

\section{ІЧ-СПЕКТРОМЕТРИЧНІ ТА ТЕРМОГРАВІМЕТРИЧНІ ДОСЛІДЖЕННЯ КОМПЛЕКСІВ КОБАЛЬТУ, КУПРУМУ ТА ЦИНКУ НА ОСНОВІ ГЛІФОСАТУ}

На основі гліфосату (N-фосфонометилгліцину $\mathrm{H}_{3} L$ ), ліганду карбациламінфосфорильного типу, синтезовано координаційні сполуки з Со(II), Cu(II), Zn(II). Комплекси досліджено методами ІЧ-, електронної спектроскопії дифузного відбиття, тер-

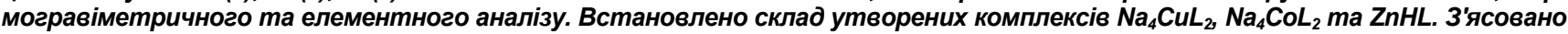
умови синтезу вказаних сполук. Запропоновано способи координації ліганду.

Ключові слова: карбациламідофосфати, гліфосат, комплекси 3d-металів, термогравіметрія.

Вступ. Інтенсифікація сільського господарства веде до зростання антропогенного навантаження на ґрунти і суміжні середовища внаслідок використання пестицидів та гербіцидів. Мінімізація такого впливу шляхом координації органічних гербіцидів з металами у кінетично, термодинамічні та термічно стабільні комплекси має надзвичайну актуальність. Дослідження координаційних сполук одного з найрозповсюджених гербіцидів суцільної дії, гліфосату (Roundup Ready (N-фросфоонометилгліцин $\mathrm{H}_{3} \mathrm{~L}$ ), відомого як високоефективний, системний та малотоксичний (3 клас небезпеки) гербіцид [1], набуває все більшого інтересу з точки зору як екологічної, так i координаційної хімії (рис.1). Основною фуннццією цієї сполуки є знищення багаторічних бур'янів на ґрунтах різного призначення.<smiles>O=C(O)CNCC(=O)O</smiles>

Рис. 1. Структурна формула гліфосату

Відомо, що гліфосат - похідна сполука від амінокислоти гліцину і в розчинах може існувати як цвіттер-іон [2]. Дана властивість дає змогу припустити різноманітне поводження молекули гліфосату в ролі ліганду. Дисоціація гербіциду протікає за схемою (рис. 2).

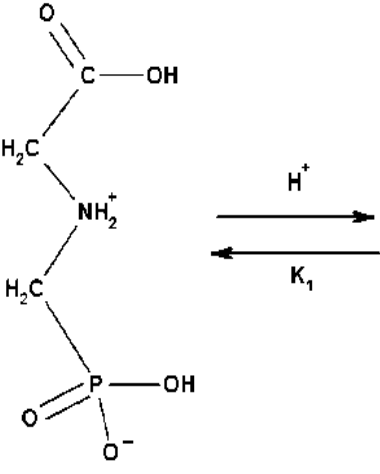

I

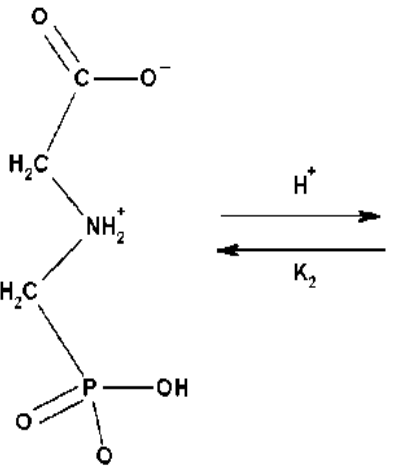

II

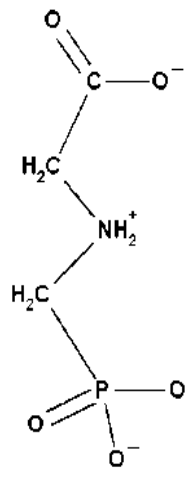

III
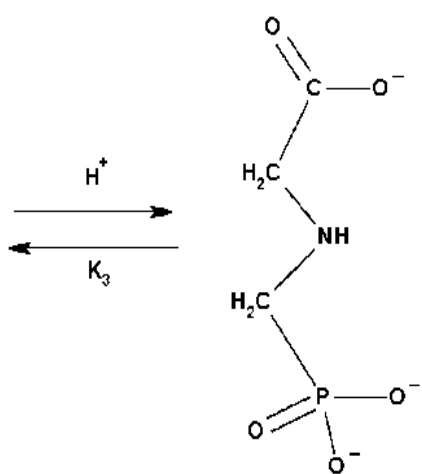

IV

I - цвіттер-іон, II - моно-аніон (pH=4), III - ді-аніон (pH=8), IV - три-аніон $(\mathrm{pH}=12)$ 
Даний ліганд $\mathrm{H}_{3} \mathrm{~L} \quad$ характеризується здатністю утворювати комплекси з 3d-металами $[3,4,5,6]$. Дослідження комплексів з Cu (II) та Co(II) показали прерогативу гідротермального синтезу для їхнього отримання, з різними способами координації ліганду [3, 4]. Гліфосат містить три функціональні групи (амінну, карбоксильну і фоссфатну) i, залежно від $\mathrm{pH}$ реакційного середовища, ступеня депротонування, може координувати іон металу тридентатно через нітроген амінної групи, оксиген карбоксильної та фросфратної груп (рис. За) або тетрадентатно, якщо координація по фоссратній групі відбувається через два атоми оксигену (рис. 3б) [7].<smiles>O=P1(O)CN2CC(O)O[Al](N2)O1</smiles>

a

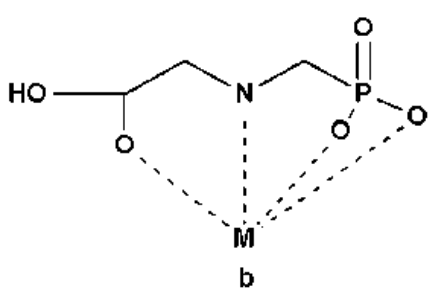

b

Рис. 3. Способи координації $\mathrm{H}_{3} \mathrm{~L}$ :

а - тридентатно, б - тетрадентатно

Таким чином, як сильний хелатоутворюючий агент гліфосат викликає гіперакумуляцію іонів міді та інших металів, таких як Co, Fe, Cu, Zn у ґрунтах і рослинах. Досліджена фунгіцидна фрункція гліфосату в комплексі з міддю [8].

3 іншого боку, наявність фосфорильної, аміно- та карбокси- групи (рис. 1), а також загальна фрормула $\mathrm{HOOCCH}_{2} \mathrm{NHCH}_{2} \mathrm{P}(\mathrm{O})(\mathrm{OH})_{2}$ свідчать про схожість цієї сполуки з карбоциламідофосфратами (КАФ) - сполуками, що $є$ бідентантними О,О-донор лігандами, з загальною формулою $\mathrm{R}^{1} \mathrm{C}(\mathrm{O}) \mathrm{NHP}(\mathrm{O}) \mathrm{R}^{2}$ (де $\mathrm{R}^{1}$ - Alk, -Ar, $\mathrm{R}^{2}-\mathrm{N}(\mathrm{Alk})_{2}$, OAlk, -OAr) (рис. 4).<smiles>[R]C(=O)N([R7])P([R])([R])=O</smiles>

Рис. 4. Структурна формула КАФ лігандів, ge $\mathrm{R}^{1}$ - Alk, -Ar, R ${ }^{2}-\mathrm{N}(\text { Alk })_{2}$, OAlk, -OAr

Науковий інтерес зазначених координаційних сполук 3 КАФ лігандами неоднаразово доведений в роботах $[9,10]$. Де вони демонструють широкий спектр біологічної активності при диагностиці і лікуванні раку [11]; виявляють люмінісцентні властивості [12]; координаційна поведінка КАФ $€$ різноманітною та добре вивченною [13]. Тому метою даної роботи було встановити оптимальні умови синтезу стійких координаційних сполук гліфосату з іонами $\mathrm{Cu}(\mathrm{II}), \mathrm{Co}(\mathrm{II})$ i Zn(II), з'ясувати склад та будову утворених комплексних сполук та запропонувати тип координації.

Об'єкти та методи дослідження. В експериментальній роботі як розчинники використовували дистильовану воду та абсолютизований метиловий спирт. Зневоднення та очистку виконували за допомогою стандартних препаративних методів [14]. ІЧ-спектри реєстрували за допомогою спектрометра "Perkin-Elemer Spectrum BX", в області 400$4000 \mathrm{~cm}^{-1}$, зразки у вигляді таблеток $\mathrm{KBr}$. Електронні спектри відбиття розчинів координаційних сполук в області 200-800 нм реєстрували на приладі Termosantific Evolution 600. Елементний аналіз проводився на аналізаторі vario MICRO Cube ELEMENTAR. Термічний аналіз здійснювали на дериватограсрі DTG-60H, який дає можливість для одного зразка одночасно визначити втрату маси (термогравіметричний ТГ) та теплові ефекти (диференційно-термічний аналіз ДТА). Дослідження здійснювали в динамічному режимі в атмосфері повітря. Зразки нагрівали у платиновому тиглі зі швидкістю 10 K/хв до температури 1073 К. Як стандартний зразок використовували $\mathrm{Al}_{2} \mathrm{O}_{3}$.

Виділення ліганду N-(фоссоонометил)гліцина з промислового препарату "RoundUp" (водний розчин $\mathrm{K}_{2} \mathrm{HL}$ жовтого кольору, $\rho=662$ /л) проводили за стандартною методикою. Концентрований розчин калійної солі підкислювали хлороводневою кислотою до $\mathrm{pH} \sim 1,5$. Осад, що випав, відфільтровували, двічі промивали водою до нейтрального рН і висушували на повітрі до постійної маси. В результаті отримали білі кристали гліфосата, які були використані як ліганд ( $\mathrm{Mr}=169,08$ г/моль).

Чистоту препарату $\mathbf{H}_{3} \mathbf{L}$ встановлювали методом ПMP з використанням NaOD у важкій воді $\left(\mathrm{D}_{2} \mathrm{O}\right)$, а трucтриетиламонійної солі в розчині $\mathrm{DMSO}\left(\mathrm{D}_{6}\right)$ та методом ІЧ-спектроскопії.

Синтез координаційних сполук з використанням гідратованих хлоридів $d$-металів кваліфікації "х.ч." та "ч.д.а." без попередньої очистки та зневоднення. Кількість кристалізаційної води визначали за результатами трилонометричного аналізу на метал за методиками [15]. Чистота реактивів контролювалася ІЧ-спектроскопією та елементним аналізом. Приготування серії комплексів купруму, кобальту та цинку проводили шляхом депротонування гліфросату водним розчином лугу та подальшої взаємодії депротонованої форми ліганду з водним розчином солі у зазначених мольних співвідношеннях. Через 3-5 днів утворювались кристали.

Синтез комплексних солей $\mathrm{Co}(\mathrm{II}), \mathrm{Cu}(\mathrm{II})$ та $\mathrm{Zn}(\mathrm{II})$ виконували за схемами:

$$
\begin{array}{ll}
1 & \mathrm{H}_{3} \mathrm{~L}+\mathrm{NaOH} \rightarrow \mathrm{NaH}_{2} \mathrm{~L} \\
& 2 \mathrm{NaH} \mathrm{H}_{2} \mathrm{~L}+\mathrm{M}^{2+} \rightarrow \mathrm{M}\left(\mathrm{H}_{2} \mathrm{~L}\right)_{2} \\
2 & \mathrm{H}_{3} \mathrm{~L}+2 \mathrm{NaOH} \rightarrow \mathrm{Na}_{2} \mathrm{HL} \\
& \mathrm{Na}_{2} \mathrm{HL}+\mathrm{M}^{2+} \rightarrow \mathrm{MHL} \\
3 & \mathrm{H}_{3} \mathrm{~L}+3 \mathrm{NaOH} \rightarrow \mathrm{Na}_{3} \mathrm{~L} \\
& 2 \mathrm{Na}_{3} \mathrm{~L}+3 \mathrm{M}^{2+} \rightarrow \mathrm{M}_{3} \mathrm{~L}_{2}
\end{array}
$$

Результати та їх обговорення. 14-спектральні дослідження синтезованих координаційних сполук. Характеристичними смугами в 14 спектрах гліфросату $€$ смуги поглинання фоссрорильної, фосфатної та карбонільної груп. Методом ІЧ-спектроскопії було встановлено, що незалежно від співвідношення реагуючих компонентів (солі металу та гліфосату) за наведеними вище схемами синтезу комплексів, завжди утворюються координаційні сполуки одного типу для кожного металу. Порівнюючи 14 спектри отриманих координаційних сполук і вільного ліганду [16], можна помітити певні закономірності у зсувах характеристичних смуг поглинання та, з достатньо високим ступенем ймовірності, визначити спосіб координації ліганду та тип координованих груп (табл. 1). Участь карбоксильної групи в координації можна встановити за появою нових двох смуг, відповідних антисиметричних (1588-1610 см-1) і симетричних (1394-1400 см-1) коливань СОО- групи. Такі смуги спостерігаються у кожному з синтезованих комплексів. Значення зсуву карбоксильної групи $\Delta(\mathrm{CO})$ і фоосфатної групи $\Delta(\mathrm{PO})$ для комплексів наведено в табл. 1 
Основні смуги поглинання в ІЧ-спектрі гліфосату і комплексів $\mathrm{Na}_{4} \mathrm{CuL}_{2}, \mathrm{Na}_{4} \mathrm{CoL}_{2}, \mathrm{ZnHL}\left(\mathrm{cm}^{-1}\right)$

\begin{tabular}{|c|c|c|c|c|c|c|}
\hline \multirow{2}{*}{ Групові коливання } & \multicolumn{5}{|c|}{ Частота коливання, см $^{-1}$} & \multirow[b]{2}{*}{$\mathrm{ZnHL}$} \\
\hline & $\mathrm{H}_{3} \mathrm{~L}$ & $\mathrm{Na}_{4} \mathrm{CuL}_{2}$ & $\mathrm{Na}_{4} \mathrm{CuL}_{2}{ }^{\circ} \mathrm{C}$ & $\mathrm{Na}_{4} \mathrm{CoL}_{2}$ & $\mathrm{Na}_{4} \mathrm{CoL}_{2}{ }^{\circ} \mathrm{C}$ & \\
\hline$v(C=O)$ & 1733 & 1631 & - & 1600 & - & 1610 \\
\hline$v(C-O)^{a}$ & & 1588 & & 1605 & & 1610 \\
\hline $\mathrm{v}(\mathrm{C}-\mathrm{O})^{\mathrm{s}}$ & & 1394 & & 1400 & & 1385 \\
\hline$\delta\left(\mathrm{NH}_{2}^{+}\right)$ & 1560 & 1416 & - & 1392 & - & 1503 \\
\hline$v(P-O)^{a}$ & 1190 & 1063 & 1009 & 1046 & 1065 & 1169 \\
\hline$v(P-O)^{s}$ & 919 & 996 & & 990 & & 925 \\
\hline$\Delta(C=O) C^{-1}$ & - & 102 & - & 133 & - & 123 \\
\hline$\Delta(P O) C M^{-1}$ & - & 127 & 181 & 144 & 125 & 21 \\
\hline
\end{tabular}

Для вільного ліганду, що знаходиться у фрормі цвітеріона деформаційні коливання протонованої аміно-групи $\delta\left(\mathrm{NH}_{2}{ }^{+}\right)$знаходяться при $1559 \mathrm{~cm}^{-1}$ та $1485 \mathrm{~cm}^{-1}$. У комплексах з міддю, кобальтом та цинком спостерігається зсув цих

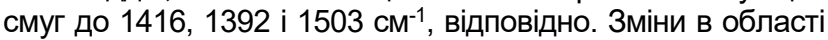
коливань карбонільної, амінної та фросфратної груп вказують на можливість координації з металом (табл. 1).

Таким чином, аналіз ІЧ-спектрів вільного ліганду та синтезованих комплексів дає можливість припустити тридентатний спосіб координації ліганду через оксиген карбонільної групи, нітроген аміногрупи та оксиген фоосфатної групи.
Електронні спектри дифузного відбиття. В електронному спектрі дифузного відбиття комплексу кобальту (II) спостерігається перехід ${ }^{4} \boldsymbol{T}_{1 g}(\boldsymbol{F}) \rightarrow{ }^{4} \boldsymbol{T}_{1 g}(P)$ в області 534 нм, який $є$ характерним для октаедричних комплексів кобальту і зумовлює його рожеве забарвлення [17].

Аналіз електронного спектру комплексу купруму (II) пов'язаний з труднощами через відсутність чітких правил співвідношення спектра зі структурою.

Елементний аналіз. За результатами елементного аналізу був підтверджений склад комплексних сполук $\mathrm{Na}_{4} \mathrm{CoL}_{2}, \mathrm{Na}_{4} \mathrm{CuL}_{2}$, ZnHL (табл. 2).

Таблиця 2

Склад синтезованих сполук за даними CHN-аналізу

\begin{tabular}{|l|l|l|l|l|l|l|}
\hline \multirow{2}{*}{} & \multicolumn{2}{|c}{$\% \mathrm{C}$} & \multicolumn{2}{c}{$\% \mathrm{H}$} & \multicolumn{2}{c|}{$\% \mathrm{~N}$} \\
\cline { 2 - 7 } & Teop. & Експ. & Teоp. & Експ. & Teоp. & Експ. \\
\hline $\mathrm{Na}_{4} \mathrm{CoL}_{2}$ & 14,9 & 14,4 & 2,5 & 3,9 & 5,7 & 5,2 \\
\hline $\mathrm{Na}_{4} \mathrm{CuL}_{2}$ & 14,7 & 14,1 & 2,05 & 2,7 & 5,7 & 5,1 \\
\hline $\mathrm{ZnHL}$ & 15,50 & 15,36 & 2,61 & 2,55 & 6,03 & 5,84 \\
\hline
\end{tabular}

Термогравіметричні дослідження. Аналіз даних ТГА та 1Ч-спектрів вільного ліганду та комплексів кобальту і міді (рис. 5, 6) до та після деструкції (табл. 1) показав, що для всіх випадків розклад проходить за трьома стадіями: 1-а стадія $100-110^{\circ} \mathrm{C}$, що супроводжується втратою води; 2-а стадія спостерігається в межах 230- $246^{\circ} \mathrm{C}$ (екзотермічна), супроводжується втратою карбоксильної групи, так як характеристична смуга поглинання $\mathrm{C}=\mathrm{O}$ групи в області $1631 \mathrm{~cm}^{-1}$ зникає при деструкції; на 3-й стадії в інтервалі температур $540-560^{\circ} \mathrm{C}$ відбувається розклад сполук з утворенням поліфоссратів.
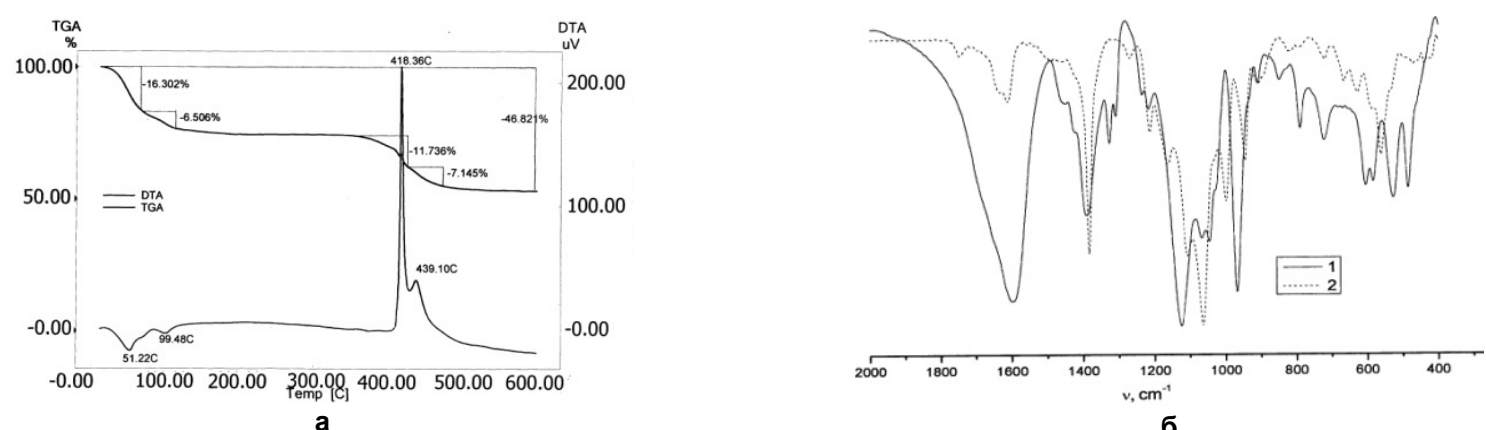

Рис. 5. a - Криві ТГ та ДТА для $\mathrm{Na}_{4} \mathrm{CoL}_{2}$

б - 14 спектри $\mathrm{Na}_{4} \mathrm{CuL}_{2}$ до (1) і після термогравіметричного аналізу (2)
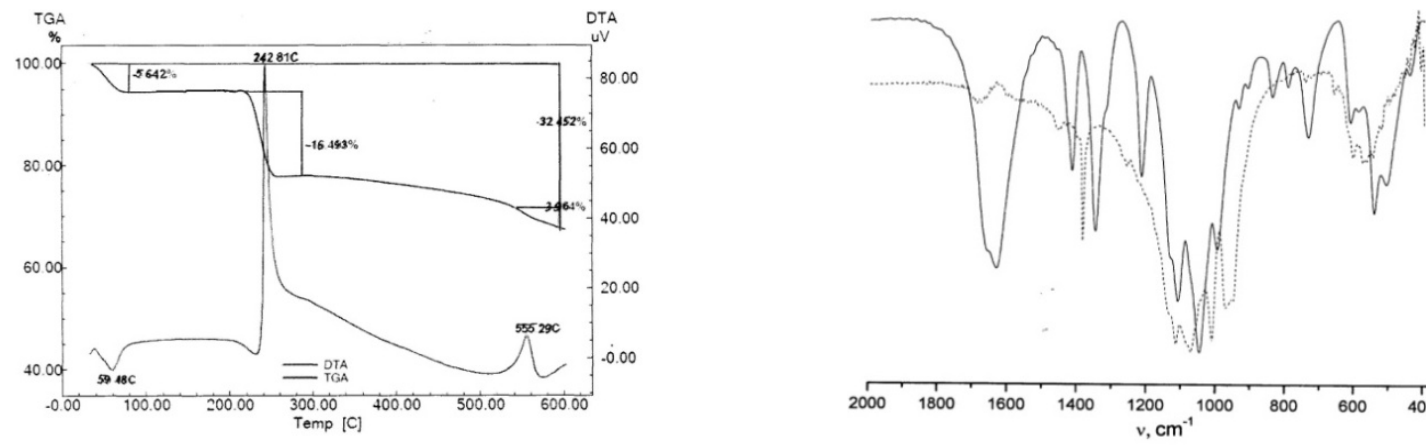

a

Рис. 6. а - Криві ТГ та ДТА для $\mathrm{Na}_{4} \mathrm{CuL}_{2}$

б - 14 спектри $\mathrm{Na}_{4} \mathrm{CuL}_{2}$ до (1) і після термогравіметричного аналізу (2) 

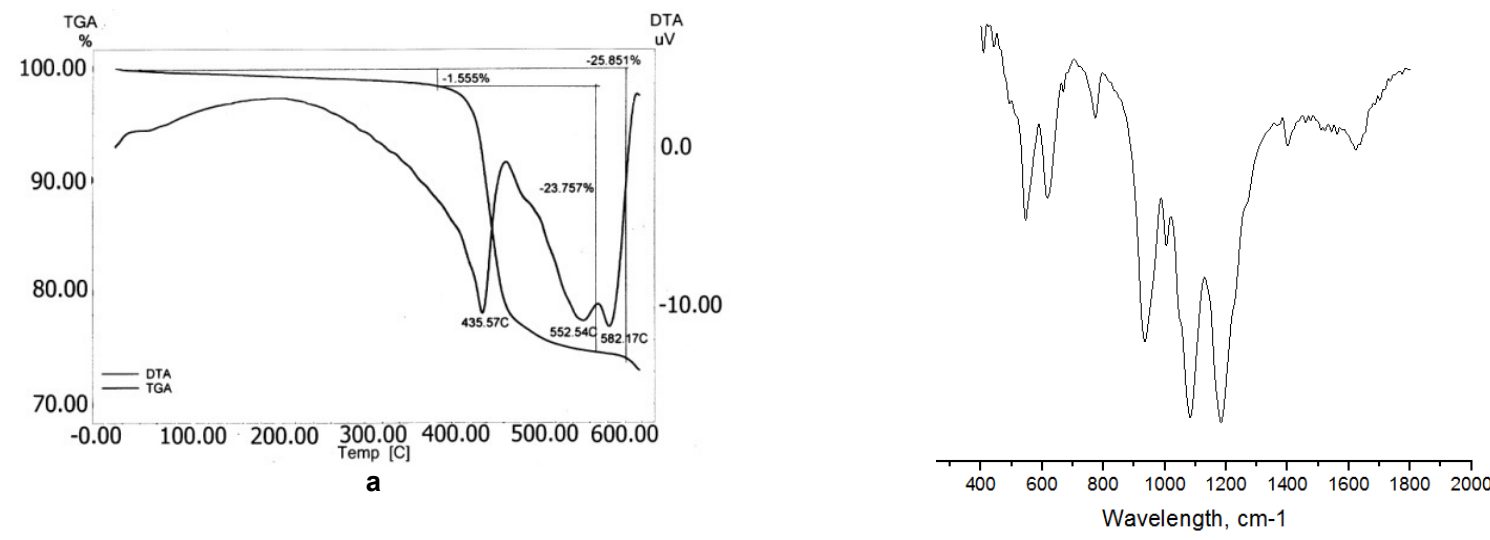

Рис. 7. а - Криві TГ та ДТА для ZnHL; б - ІЧ-спектр продуктів термогравіметричного аналізу

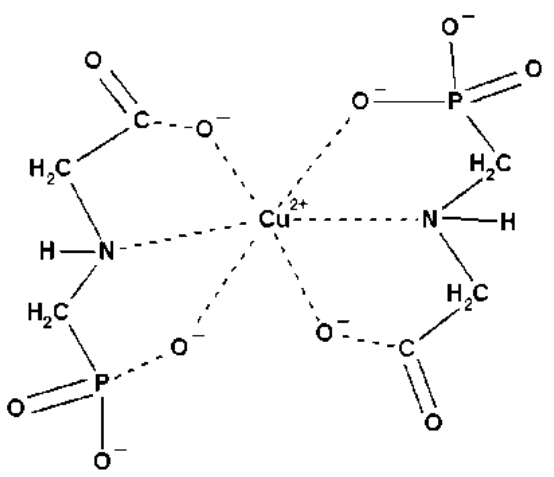

a

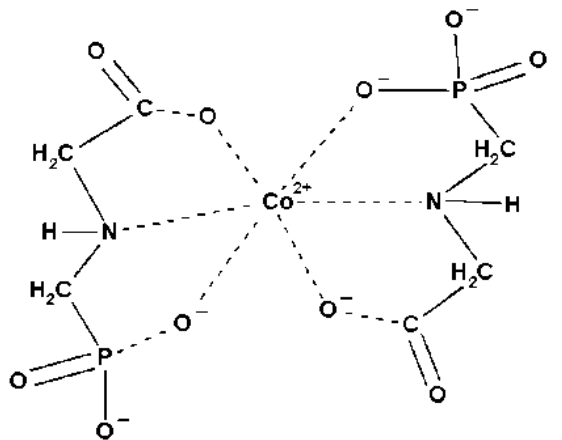

б<smiles>O=P1(O)CN2CC(O)O[Te](O)(O2)O1</smiles>

B

Рис. 8. Будова комплексів а- $\mathrm{Na}_{4} \mathrm{CoL}_{2}$, б- $\mathrm{Na}_{4} \mathrm{CuL}_{2}$, в-ZnHL

Комплекс Zn(II) з N-фросфонометилгліцином не містить кристалізаційної води, що підтверджується кривими ТГА і ДТА (рис. 7). Комплекс розкладається у дві стадії. Перша стадія (ендотермічна) проходить в інтервалі температур $370-440^{\circ} \mathrm{C}$. На другій стадії $\left(520-600^{\circ} \mathrm{C}\right)$ відбувається подальше розкладання зразку комплексу, що супроводжується подальшим окисненням проміжних продуктів.

Висновки. Синтезовано координаційні сполуки $\mathrm{Co}(\mathrm{II}), \mathrm{Cu}(\mathrm{II})$ та Zn(II) з N-фросфронометилгліцином в якості карбоніламінфоссрорильного ліганду. На підставі даних спектрального та термогравіметричного аналізу встановлено спосіб тридентатної координаціі депротонованого ліганду, гліфросату, через атоми оксигена карбонільної групи, нітрогену аміногрупи та оксигена фосфратної групи. За даними електронної спектроскопії комплексів кобальту для центрального іону передбачено КЧ 6. За данними елементного аналізу запропонований склад синтезований координаційних сполук: $\mathrm{Na}_{4} \mathrm{CuL}_{2}, \mathrm{Na}_{4} \mathrm{CoL}_{2}$, та ZnHL і представлена будова комплексів (рис. 8).

Список використаних джерел

1. Гігієнічна класифікація пестицидів за ступенем небезпечності. ДСП 8.8.1.2.002-98.

Hygienic classification of pesticides according to the degree of danger. State sanitary epidemiological control 8.8.1.2.002-98.

2. Madsen H., Christinsen H., Gotlieb-Peterson C., Acta. Chem. Scand., 1978, A 32, P. 79

3. Sheals J., Persson P., Hedman B., Inorg. Chem., 2001, 40, 4302-4309.

4. Barja B., Herszage J., dos Afonso S., Polyhedron, 2001, 20, 1821-1830.

5. Han G., Hui-Zhou L., Ye Q., Xiong R., Z. Anorg. Allg. Chem., 2008, 634, $1991-1995$
6. Sun X., Liang Z., Ma P., Ban R., Jiang M., Zhang D., Wang J., Niu J., Dalton Trans., 2015, 44, 17544-17550.

7. Clarke E.T., Rudolf P.R., Martell A.E., Clearfield A., Inorg. Chim. Acta, 1989, 164, 59-63.

8. Franz J.E., Mao M.K., Sikorski J.A. Glyphosate: A Unique Global Herbicide. Washington, American Chemistry Society, 1997, 653 p

9. Skopenko V.V., Amirkhanov V.M., Sliva T.Yu., Vasilchenko I.S. Anpilova E.L., Garnovskii A.D., Russ. Chem. Rev., 2004, 73(8), 737-752.

10. Gubina K., Shatrava J., Ovchynnikov V., .Amirkhanov V., Polyhedron, 2000, 19, 2203-2209.

11. Oroujzadeh N., Gholivand K., Rezaei N., Jamalabadi R., Polyhedron, 2016, 28, 3731-3738.

12. Gusev A.N., Hasegawa M., Shimizu T., Fukawa T., Sakurai S., Nishchymenko G.A., Shul'gin V.F., Meshkova S.B., Linert W., Inorg. Chim. Acta., 2013, 406, 279-284.

13. Amirkhanov V., Ovchynnikov V., Trush V., Gawryszewska P., Jerzykiewicz L.B. Powerful new ligand systems: carbacylamidophosphates (CAPh) and sulfonylamidophosphates (SAPh). In: Ligands. Synthesis, characterization and role in biotechnology. New York, Nova Science Publishers Inc., 2014, 199-248.

14. Гордон А. Спутник химика: физико-химические свойства, методики, библиография / А. Гордон, Р. Форд. - М. : Мир, 1976. - 541 с.

Gordon A., Ford R. The chemist's companion: A handbook of practical data, techniques, and references, Mir, Moscow, 1976, 541 p.

15. Шварценбах Г. Комплексонометрическое титрование / Г. Шварценбах, Г. Флашка. - М. : Мир, 1970. - 321 с.

Shvarcenbach G., Flashka G. Complexometric titration. Moscow: Khimija, 1970, 321.

16. Picoolo A., Celano G., Environ J. Sci. Health, 1993, B28, 447-457.

17. Ливер Э. Электронная спектроскопия неорганических соединений / Э. Ливер. - М. : Мир, 1987. - 493 с.

Liver E. Electron spectroscopy of inorganic compounds. Moscow: Mir, $1987,493 \mathrm{p}$.

Надійшла до редколегії 15.10.18 
А. Аблятипова, студ.

Т. Беруашвили, студ.

Е. Губина, канд. хим. наук, gubina@agrotest.com

Киевский национальный университет имени Тараса Шевченко, Киев

\section{ИК-СПЕКТРОМЕТРИЧЕСКИЕ И ТЕРМОГРАВИМЕТРИЧЕСКИЕ ИССЛЕДОВАНИЯ КОМПЛЕКСОВ КОБАЛЬТА (ІІ), МЕДИ (II) И ЦИНКА (II) НА ОСНОВЕ ГЛИФОСАТА}

Синтезированы координационные соединения на основе глифосата (N-фоосфонометилалицина) с Co(II), Cu(II) и Zn(II). Проведено сравнение комплексообразования данного лиганда с карбациламидофосфатами. Координационные соединения исследованы методами ИК-, электронной спектроскопии диффузного отражения, термогравиметрического и элементного анализа. Установлено, что лиганд в указаных комплексных соединениях координируется тридентатно через азотаминогруппы и кислороды карбонильной и одной из фосфатных групп. Предложен состав синтезированных соединений: $\mathrm{Na}_{4} \mathrm{CuL}_{2}, \mathrm{Na}_{4} \mathrm{CoL}_{2} \mathrm{U} \mathrm{ZnHL}$.

Ключевые слова: карбациламинофосфаты, глифосат, комплексы 3d-металлов, ИК- спетроскопия, термогравиметрия.

A. Ablyatipova, stud.,

T. Beruashvili, stud.

K. Gubina, PhD, gubina@agrotest.com

Taras Shevchenko National University of Kyiv, Kyiv

\section{IR-SPECTROSCOPIC AND THERMOGRAVIMETRIC STUDIES OF THE COBALT, COPPER AND ZINC COMPLEXES BASED ON GLYPHOSATE}

The complexes with $\mathrm{Co}(\mathrm{II}), \mathrm{Cu}(\mathrm{II})$ and $\mathrm{Zn}$ (II) based on glyphosate ( $\mathrm{N}$-phosphonomethylglycine) have been synthesized and studied by means of IR-, electron diffusion spectroscopies, thermogravimetric and elemental analysis. The coordination behavior between glyphosate and carbacylamidophosphates was compared. By means of IR spectroscopy, it was found that regardless of the ratio of reacting components (metal salt and glyphosate) the coordination compounds of the same type for each metal are always formed. The spectrum of the glyphosate and complexes with it can be divided into two parts, corresponding to the different donor groups of the ligand. Between 1500 and $1800 \mathrm{~cm}^{-1}$ strong peaks are found, mostly associated with stretching motions of the carboxylate group, while the region $800-1200 \mathrm{~cm}^{-1}$ is dominated by peaks originating from the phosphonate. The changes in frequencies of phosphate $P-O\left(\triangle(P O)=127 \mathrm{~cm}^{-1}\right.$ for $\mathrm{Na}_{4} \mathrm{CuL}_{2}, 144 \mathrm{~cm}^{-1}$ for $\mathrm{Na}_{4} \mathrm{CoL}_{2}$ and $21 \mathrm{~cm}^{-1}$ for $\mathrm{ZnHL}_{\text {) }} \mathrm{NH}_{-}$and $\mathrm{C}=\mathrm{O}$ $\left(\triangle(C O)=102 \mathrm{~cm}^{-1}\right.$ for $\mathrm{Na}_{4} \mathrm{CuL}_{2}, 133 \mathrm{~cm}^{-1}$ for $\mathrm{Na}_{4} \mathrm{CoL}_{2}$, and $123 \mathrm{~cm}^{1-}$ for $\left.\mathrm{ZnHL}\right)$ peaks indicate the involvement of these groups in coordination. The $v(C-O)_{a}$ is shifted to higher frequency and broadened.

The thermal decomposition process of glyphosate was studied by the DT and TG analysis. The results showed that the thermal decomposition temperature of glyphosate was above $198^{\circ} \mathrm{C}$. And the decomposition process was divided into three stages: the zero stage is the decomposition of impurities, and the mass loss in the first and second stage may be methylene and carbonyl, respectively. It has been found that the ligand in the mentioned complexes is coordinated tridentivly via the nitrogen atom of amino group and oxygen atoms of the carbonyl and phosphate groups.

The electronic spectrum of diffuse reflection of the cobalt (II) complex showed only one peak in the $534 \mathrm{~nm}$ region, corresponding to ${ }^{4} T_{1 g}(F) \rightarrow{ }^{4} T_{1 g}(P)$ transition. This fact indicating the octahedral environment of the cobalt atom in complexes and causes its pink coloration. On the base of TGA and DTA analysis, IR spectroscopy and elemental analysis, the following compositions of the complexes were proposed: Na4CuL2, $\mathrm{Na}_{4} \mathrm{CoL}_{2}$ and $\mathrm{ZnHL}$. Based on the literature data and our studies it was assumed that above structures contain fivemembered chelate rings with the amine, carboxylate, and phosphonate groups of the glyphosate ligand involved in chelation. Unlike 3d-metal complexes with carbacylamidophosphates, the phosphoryl group of glyphosate does not participate in coordination.

Keywords: carbacylaminophosphates, glyphosate, 3d-complexes, IR, TGA, DTA.

М. Стругацька, студ., І. Олишевець, асп., olishevetsirina@gmail.com, В. Овчинніков, канд. хім. наук, В. Амірханов, д-р хім. наук Київський національний університет імені Тараса Шевченка, Київ

\section{СИНТЕЗ ТА СПЕКТРАЛЬНІ ВЛАСТИВОСТІ КОМПЛЕКСІВ ЛАНТАНОЇДІВ 3 НОВИМ ТРИПОДАЛЬНИМ ТРИСХЕЛАТУЮЧИМ КАФ ЛІГАНДОМ}

Синтезовано новий триподальний трисхелатуючий ліганд карбациламідофосфатного типу $\mathrm{H}_{3} \mathrm{~L}=\mathrm{N}\left(\mathrm{CH}_{2} \mathrm{CH}_{2} \mathrm{~N}(\mathrm{H}) \mathrm{C}(\mathrm{O}) \mathrm{N}(\mathrm{H}) \mathrm{P}(\mathrm{O})\left(\mathrm{OCH}_{3}\right)_{2}\right)_{3}$ i на його основі одержано та виділено в кристалічному стані ряд координаційних сполук складу $L n L$, de Ln = La, Nd, Eu, Tb. Отримані сполуки досліджено за допомогою ${ }^{1} H$ ЯMP, 14 та електронної спектроскопії. Встановлено, що хелатуючі фрагменти ліганду координуються до центрального іона бідентатно-циклічно через атоми оксигену карбонільної та фосфорильної груп. Досліджено термічні властивості координаційної сполуки неодиму та встановлено наявність молекул води в координаційній сфері. За даними електронної спектроскопії комплексу NdL для центрального іону в досліджених комплексах визначено Кч 8.

Ключові слова: карбациламідофосфати, лантаноїди, координаційні сполуки.

Вступ. Останнім часом дослідження координаційних сполук лантаноїдів інтенсивно розвивається, що пов'язано $з$ перспективністю їх практичного застосування у новітніх технологіях, біології та медицині [1]. Через здатність комплексів лантаноїдів випромінювати у досить вузькому спектральному діапазоні, велика кількість досліджень спрямована на створення на їх основі нових люмінофорних матеріалів [2]. Сполуки Р3Е можуть знайти застосування в медицині як контрастні речовини при МРТдослідженнях [3], люмінесцентних зондів [4], антиоксидантів, протипухлинних засобів, що проявляють цитотоксичність відносно різних видів ракових клітин тощо [5].

Протягом останніх десятиліть опубліковано багато робіт, присвячених використанню комплексів лантаноїдів у технології органічних електролюмінесцентних діодів (OLED) [6], значна частина яких припадає на вивчення $\beta$-дикетонатних комплексів P3E $з$ додатковими лігандами-"антенами", здатними трансформувати енергію світла у збудження f-електронів [7]. Не менш перспективними, але недостатньо вивченими в цьому напрямку $€$ комплекси лантаноїдів із $\mathrm{P}, \mathrm{N}$-гетерозаміщеними структурними аналогами $\beta$-дикетонів - карбациламідофоссратами (КАФ-лігандами) - сполуками, що містять хелатуючий фррагмент $\mathrm{C}(\mathrm{O}) \mathrm{NHP}(\mathrm{O})$ [8]. Наявність атома фоссфору у складі функціонального фрагменту надає додаткові синтетичні можливості (порівняно з $\beta$-дикетонами) для введення функціональних груп-"антен".

Триподальні ліганди - це особливий клас ациклічних іонофорів, які складаються з мультиклешневих лігандів, кожна гілка яких несе хелатуючу функціональну групу. 